\title{
Adverse effects of Croton urucurana B. exposure during rat pregnancy
}

\author{
Rafaianne Queiroz Moraes-Souza ${ }^{a, b}$, Thaigra Sousa Soares ${ }^{a, b}$, Nágilla Orleanne Lima Carmo ${ }^{a}$, \\ Débora Cristina Damasceno ${ }^{\mathrm{b}}$, Kleber Eduardo Campos $^{\mathrm{a}}$, Gustavo Tadeu Volpato ${ }^{\mathrm{a}, \mathrm{b}, *}$ \\ a Laboratory of System Physiology and Reproductive Toxicology, Institute of Biological and Health Sciences, Federal University of Mato Grosso (UFMT), \\ Barra do Garças, Mato Grosso State, Brazil \\ ${ }^{\mathrm{b}}$ Laboratory of Experimental Research on Gynecology and Obstetrics, Graduate Course of Gynecology, Obstetrics and Mastology, Univ Estadual Paulista \\ Unesp, Botucatu, São Paulo State, Brazil
}

\section{A R T I C L E I N F O}

\section{Keywords:}

Croton urucurana

Plant

Toxicity

Malformation

Pregnancy

\begin{abstract}
A B S T R A C T
Ethnopharmacological relevance: Several women often use plant extracts during pregnancy without any concern about its possible toxic effects. The plant effects have been experimentally confirmed in animals and humans, while others require additional investigations.

Aim of study: To evaluated the effect of aqueous extract of Croton urucurana latex on the maternal-fetal repercussions in rats.

Methods: Pregnant rats were randomly distributed into four experimental groups: Control=treated with water (vehicle); Treated 200=treated with a dose $200 \mathrm{mg} / \mathrm{kg}$; Treated 400= dose $400 \mathrm{mg} / \mathrm{kg}$ and; and Treated $800=$ dose $800 \mathrm{mg} / \mathrm{kg}$. The rats were orally treated by gavage with Croton urucurana or vehicle (water) during whole pregnancy. At term of pregnancy, all rats were killed to obtain maternal blood and tissues samples and fetal weight and anomaly analyses.

Results: C. urucurana treatment (Treated 400 and Treated 800) showed elevated liver enzymatic activities, reduced fetal body weight and placental efficiency. The Treated 800 group presented increased maternal total protein and cholesterol levels, and heart relative weight. All treated groups presented reduced maternal body weight and food intake, and increased pre-implantation loss rate compared to those of Control group. In addition, the treatment contributed to increased skeletal and visceral anomalies with higher doses.

Conclusion: Croton urucurana treatment caused maternal toxicity, which contributed for impairment embryo fetal development. These results showed that the indiscriminate use of plants during pregnancy should be avoided to prevent potential risk on maternal health as well as their offspring.
\end{abstract}

\section{Introduction}

Medicinal plants have been widely used to treat a variety of diseases. However, the use of these plants during pregnancy may present health risks to the woman and also to her fetus (Moreira et al., 2014). Certain herbs, used as abortifacients can induce embryotoxicity, fetotoxicity and/or teratogenicity when embryonic death does not occur. Croton urucurana Baillon, popularly known as dragon blood, blood water, capixingui, urucuana, lucurana, tapexingui and tapixingui, is considered an abortive plant (Gurgel et al., 2002). Croton is a large and diverse genus of Euphorbiaceae that comprises at least 800 species of the tropics and subtropics (Webster, 1993). C. urucurana is widespread in wetlands and riparian areas and is commonly found in southern Brazil, northern Argentina, Paraguay and Uruguay. The $C$. urucurana tree has an open canopy and bright stem, and reaches up to $15 \mathrm{~m}$ (Babieri et al., 2014).
The indigenous culture believe that $C$. urucurana shows remarkable healing properties. This plant has been extensively used in folk medicine for treatment of cancer, rheumatism, lesions, ulcers, diarrhea infections (Rao et al., 2007). Three different products from $C$. urucurana species are primarily used - the red sap or latex, stem bark and the gum exudate (Simionatto et al., 2007). In male rats, Esmeraldino et al. (2005) found that the stem bark of C. urucurana aqueous extract showed anti hemorrhagic activity. Also in male rats, was observed an anti-diarrheal response after treatment with $600 \mathrm{mg} /$ $\mathrm{kg}$ of C. urucurana latex (Gurgel et al., 2001), and antifungal activity against five different dermatophytes when using C. urucurana sap in an in vitro study (Gurgel et al., 2005). Cordeiro et al. (2012), testing the acute toxicity of this plant, demonstrated that a single dose of $2000 \mathrm{mg} / \mathrm{kg}$ of C. urucurana bark methanol extract produced no toxicity signs in female rats, whereas doses at 50, 100 and $250 \mathrm{mg} /$ $\mathrm{kg}$ caused reduced gastric lesions in male rats. In 2016, these same

\footnotetext{
* Corresponding author at: Laboratório FisioTox, Instituto de Ciências Biológicas e da Saúde - UFMT, Av. Valdon Varjão, 6390, 78600-000, Barra do Garças, Mato Grosso, Brazil.

E-mail address: gtvolpato@yahoo.com (G.T. Volpato).
} 
authors found that the C. urucurana bark methanol extract exhibited anti-inflammatory and antinociceptive properties in male mice (Cordeiro et al., 2016).

In spite of the widespread use of C. urucurana by women, no studies on the use of this plant during pregnancy are available. Given that Croton urucurana is strongly suspected of causing maternal and fetal damages, the objective of this study was to assess the effect of $C$. urucurana latex aqueous extract on maternal reproductive toxicity and fetal development in laboratory animals.

\section{Materials and methods}

\subsection{Drugs and chemicals}

Drugs and chemicals secured for the study included sodium thiopental (Thiopentax Cristália Chemical Ltda., Brazil), total proteins, triglycerides, total cholesterol and high-density lipoprotein (HDL)-cholesterol, aspartate transaminase (AST) and alanine transaminase (ALT) (Wiener ${ }^{\circ}$ Rosário, Argentina). All reagents used in this study were acquired of Merk (São Paulo, Brazil).

\subsection{Extraction of plant materials}

Croton urucurana Baillon specimens were collected from Barra do Garças, Mato Grosso State, Brazil, between April and May 2009, in the morning period. The plant was identified and authenticated by experts from Mato Grosso Federal University, Mato Grosso State, Brazil, where a voucher specimen (Number 05360) has been deposited.

\subsection{Preparation of extract aqueous of Croton urucurana latex}

To obtain the latex was held vertical section of approximately $1.60 \mathrm{~m}$ long in the trunk of the tree, and then several other form of "V" cuts were made. Trees were chosen with a diameter less than $20 \mathrm{~cm}$. The latex was frozen and kept in a freezer until the time of use. On the day of the experiment, the lyophilized latex was diluted in filtrated water in a proportion of $200 \mathrm{mg}$ per $\mathrm{ml}$ of water.

\subsection{Experimental animals}

Female and male Wistar rats weighing approximately 240 and $260 \mathrm{~g}$, respectively, were obtained from CEMIB (Multidisciplinary Center for Biological Research) - Campinas State University (UNICAMP). These animals were adapted and maintained in Vivarium of Laboratory of System Physiology and Reproductive Toxicology, Mato Grosso State, Brazil, under standard laboratory conditions $\left(22 \pm 3{ }^{\circ} \mathrm{C}, 12\right.$-h light/dark cycle), with pelleted food (Purina rat chow, Purina ${ }^{\circ}$ São Paulo, Brazil) and tap water ad libitum. The animals were cared for in accordance with the principles of the Guide for Care and Use of Experimental Animals. The local Committee of Ethics in Animal Experimentation approved all experimental procedures of this study (Protocol number 23108.026432/12-0).

\subsection{Mating procedure and experimental groups}

All female rats were mated overnight to male rats. The morning when sperm was found in the vaginal smear was designated as day 0 of pregnancy. The mating procedure consisted for 15 consecutive days, which comprises approximately three-oestral cycle, however nonmated female rats in this period were considered infertile and removed of the study (Santos et al., 2015). After mating period, the pregnant rats were distributed into four experimental groups ( $\mathrm{n}$ minimum $=12$ animals/group): Control $=$ treated with water (vehicle); Treated 200= treated at dose $200 \mathrm{mg} / \mathrm{kg}$; Treated $400=$ treated at dose $400 \mathrm{mg} / \mathrm{kg}$; and Treated $800=$ treated at dose $800 \mathrm{mg} / \mathrm{kg}$. The rats were treated with C. urucurana or vehicle (water) in the morning period by intragastric route (gavage) during pregnancy (from gestational day $0-21)$.

\subsection{Course of pregnancy}

Maternal weight, food and water intake were measured in the beginning and end of pregnancy, at approximately 9 a.m. At day 21 of pregnancy, the rats were lethally anesthetized by sodium thiopental. The gravid uterus was dissected to count dead and live fetuses, resorption (embryonic death), implantation sites, and corpora lutea numbers. The number of undetectable implantation sites was determined by Salewski (1964). The rate of pre-implantation loss was calculated as: Number of corpora lutea - Number of implantations $\times 100 /$ Number of corpora lutea and for post- implantation loss rate was calculated: Number of implantations - Number of live fetuses $\times 100$ / Number of implantations (Volpato et al., 2015).

\subsection{Analysis of maternal biochemical parameters}

After maternal whole blood collection (day 21 of pregnancy), an aliquot was centrifuged at $3500 \mathrm{rpm}$ for obtaining serum. The serum sampl $\varnothing$ s were then stored at $-20^{\circ} \mathrm{C}$ for measurement of total protein, triglycerides, total cholesterol and high-density lipoprotein (HDL)cholesterol using colorimetric assay by commercial kits. Very lowdensity lipoprotein (VLDL)-cholesterol levels were determined by mathematical estimation (Knopfholz et al., 2014). Aspartate transaminase (AST) and alanine transaminase (ALT) activities were determined using commercial kits.

\subsection{Maternal organ relative weight}

The relative weight of heart, liver and kidneys of each rat was calculated by ratio of weight of each organ (grams) and body weight at day 21 of pregnancy. The result was expressed in grams/100 g body weight.

\subsection{Evaluation of the placental and fetal weight}

The fetuses and placentas were weighed to calculate the placental efficiency (fetal weight/placental weight). The mean birth weight of the control pups (Control) was $5.16 \pm 0.50 \mathrm{~g}$. Newborns in the experimental groups whose birth weights did not diverge more than $\pm 1.7 \times$ standard deviation (SD) from the Control mean (i.e., those that were within the 4.81-6.01 g range) were classified as appropriate for pregnancy age (APA). Those whose weights were at least $1.7 \times \mathrm{SD}$ greater than the Control mean birth weight were classified as large for pregnancy age (LPA). Those whose birth weights were at least $1.7 \times$ SD lower than the Control mean birth weight were classified as small for pregnancy age (SPA) (Damasceno et al., 2012).

\subsection{Analysis of external and internal (visceral and skeletal) anomalies}

The fetuses were evaluated in a microscope with respect to incidence of external anomaly. After external analysis, half of the fetuses were fixed in Bodian's solution and serial sections were prepared as described by Wilson (1965) for visceral examination. The remaining fetuses were prepared for examination of the bones by the staining procedure of Staples and Schnell (1964).

\subsection{Statistical evaluation}

For comparison of the mean values among the experimental groups, one way analysis of variance (ANOVA) followed by Tukey's Multiple Comparison test was used. The proportions were calculated by the Fisher's Exact test. For fetal data, the litter was used as statistical 
Table 1

Body weight, food and water intake of rats treated with water (Control) or Croton urucurana aqueous extract during the pregnancy.

\begin{tabular}{|c|c|c|c|c|}
\hline & \multicolumn{4}{|l|}{ Groups } \\
\hline & Control $(n=13)$ & $\begin{array}{l}\text { Treated } 200 \\
(n=13)\end{array}$ & $\begin{array}{l}\text { Treated } 400 \\
(n=13)\end{array}$ & $\begin{array}{l}\text { Treated } 800 \\
(n=12)\end{array}$ \\
\hline \multicolumn{5}{|l|}{$\begin{array}{l}\text { Body } \\
\text { weight }\end{array}$} \\
\hline Day 0 & $263.5 \pm 20.6$ & $255.9 \pm 25.7$ & $247.5 \pm 18.1$ & $260.3 \pm 21.7$ \\
\hline Day 21 & $382.1 \pm 23.0$ & $338.1 \pm 32.7^{*}$ & $332.0 \pm 48.1^{*}$ & $326.6 \pm 45.2$ \\
\hline $\begin{array}{l}\text { Weight } \\
\text { gain }\end{array}$ & $118.6 \pm 10.8$ & $82.2 \pm 39.7$ & $84.5 \pm 52.4$ & $66.3 \pm 34.1^{*}$ \\
\hline \multicolumn{5}{|l|}{$\begin{array}{l}\text { Food } \\
\text { intake }\end{array}$} \\
\hline Day 0 & $17.6 \pm 3.1$ & $18.5 \pm 2.0$ & $17.0 \pm 4.1$ & $17.0 \pm 3.6$ \\
\hline Day 21 & $25.1 \pm 5.0$ & $20.1 \pm 5.0^{*}$ & $19.5 \pm 4.1^{*}$ & $17.5 \pm 4.6^{*}$ \\
\hline \multicolumn{5}{|l|}{$\begin{array}{l}\text { Water } \\
\text { intake }\end{array}$} \\
\hline Day 0 & $33.0 \pm 8.9$ & $36.1 \pm 7.0$ & $36.3 \pm 7.2$ & $35.0 \pm 8.5$ \\
\hline Day 21 & $53.4 \pm 9.4$ & $41.5 \pm 12.8$ & $45.2 \pm 11.6$ & $45.8 \pm 10.0$ \\
\hline
\end{tabular}

Data shown as mean \pm standard deviation (SD)

${ }^{*} p<0.05$ - compared to Control group (ANOVA followed Tukey's Multiple Comparison test).

unit. Differences were considered statistically significant when $p<0.05$.

\section{Results}

As shown in Table 1, all doses of Croton urucurana extract decreased maternal body weight and food consumption at day 21 of pregnancy. The Treated 800 group reduced weight gain mean compared to Control group. There was no difference in water intake the evaluated days.

The Treated 800 group presented increased total protein and cholesterol levels, and also ALT and AST activities compared to those of other groups. In the Treated 400 group, AST activities were increased in relation to those of Control and Treated 200 groups (Table 2).

The relative weight of maternal heart was increased after treatment with the dose of $800 \mathrm{mg} / \mathrm{kg}$ of $C$. urucurana in relation to other groups. However, the remaining organs presented no significant difference among the experimental groups (Table 3).

C. urucurana treatment in all doses exhibited a significant increase in pre-implantation loss rate. The postimplantation loss rate did not differ among experimental groups as shown in Fig. 1.

The Treated 400 and 800 groups presented decreased fetal body weight and fetuses classified as appropriate for pregnancy age. These groups also showed increase in rate of fetuses classified as small for pregnancy age compared to those of Control and Treated 200 groups.
The Treated 400 group exhibited increased placental weight in relation to Control group. All groups treated with C. urucurana presented decreased placental efficiency compared to Control group (Table 4).

The Table 5 presented data about the fetal anomalies incidence. No significant differences among the experimental groups with respect to frequency of external anomalies were found. The frequency of skeletal anomalies (incomplete ossification of skull and sternebra) were elevated in Treated 800 group compared to Control group. All groups treated with $C$. urucurana aqueous extract showed abnormally shaped sternebra in relation to Control group. The frequency of visceral anomalies (dilated trachea) were increased in the Treated 400 and 800 groups compared to Control and Treated 200 groups.

\section{Discussion}

The present study evaluated the effects of aqueous extract of Croton urucurana latex on maternal reproductive toxicity and fetal development of Wistar rats aiming at elucidate popular use as abortive agent. The rats received this plant extract during pregnancy and these presented a reduced food intake and a progressive reduction of body weights in different doses tested. In addition, the rats showed a diminished maternal weight gain, indicating maternal toxicity in higher dose of extract $(800 \mathrm{mg} / \mathrm{kg})$. According to the Environmental Protection Agency (Environmental Protection Agency (EPA), 1996), reduced body and gain weight may reflect a multiplicity of responses, including anorexia or treatment-induced systemic toxicity.

The increase of total protein and cholesterol levels in the group treated with the highest dose was found in this study. These findings could be related to impaired liver metabolism, confirmed by increased AST and ALT concentrations, which might compromise the carbohydrate, protein and fat metabolism (Giannini et al., 2005). The ALT enzyme is primarily limited to the cytosol of hepatocytes and considered a highly sensitive indicator of hepatocellular damage and within limits could provide a quantitative assessment of the degree of damage sustained by the liver. However, less specific, the AST also indicates hepatic damage (Al-Habori et al., 2002). The changes in protein, cholesterol, AST and ALT levels in the present study indicate that the treatment $C$. urucurana with the higher doses caused injury in liver cells.

The rats treated with $800 \mathrm{mg} / \mathrm{kg}$ presented increase in relative weight of the maternal heart. There is evidence AST is an enzyme present in a large number of tissues, such as heart (Al-Habori et al., 2002; Giannini et al., 2005). The increase total protein levels is related to higher blood viscosity, like protein cleavage and tryptophan concentration (Cicha et al., 1999; Li et al., 2010); and this biomarker may also increases the heart loading for blood pressure (De Simone et al., 2005). Moreover, the hyperproteinemia followed by AST activity may lead to the increased of the heart weight.

With regard to maternal reproductive performance, the pre-im-

Table 2

Biochemical profile of rats treated with water (Control) or Croton urucurana aqueous extract during pregnancy.

\begin{tabular}{|c|c|c|c|c|}
\hline & \multicolumn{4}{|l|}{ Groups } \\
\hline & Control $(n=13)$ & Treated $200(n=13)$ & Treated $400(n=13)$ & Treated $800(n=12)$ \\
\hline Total protein $(\mathrm{g} / \mathrm{dL})$ & $4.0 \pm 0.8$ & $3.6 \pm 0.4$ & $4.1 \pm 0.4$ & $5.6 \pm 1.5^{*, \#, \$}$ \\
\hline Triglycerides (mg/dL) & $191.6 \pm 98.5$ & $126.1 \pm 67.0$ & $146.2 \pm 44.5$ & $199.1 \pm 65.6$ \\
\hline Cholesterol (mg/dL) & $90.5 \pm 17.2$ & $72.4 \pm 9.7$ & $79.6 \pm 13.2$ & $144.0 \pm 58.0^{*}, \#$, \\
\hline HDL-cholesterol (mg/dL) & $35.5 \pm 11.8$ & $44.9 \pm 6.3$ & $42.9 \pm 5.3$ & $55.0 \pm 23.1$ \\
\hline VLDL-cholesterol (mg/dL) & $38.1 \pm 19.5$ & $24.9 \pm 13.3$ & $29.1 \pm 8.9$ & $39.6 \pm 12.9$ \\
\hline $\operatorname{ALT}(\mathrm{U} / \mathrm{L})$ & $31.2 \pm 11.5$ & $47.9 \pm 11.1$ & $37.0 \pm 10.2$ & $81.5 \pm 20.7^{*, \#, \$}$ \\
\hline AST (U/L) & $151.4 \pm 9.2$ & $147.7 \pm 33.1$ & $198.4 \pm 33.3^{*},{ }^{\#}$ & $400.6 \pm 90.9^{*}, \#$, \\
\hline
\end{tabular}

Data shown as mean \pm standard deviation (SD).

${ }^{*} p<0.05$ - compared to Treated 200 group (ANOVA followed Tukey's Multiple Comparison test).

\# $p<0.05$ - compared to Treated 200 group (ANOVA followed Tukey's Multiple Comparison test).

$\$ p<0.05$ - compared to Treated 400 group (ANOVA followed Tukey's Multiple Comparison test). 
Table 3

Relative weight of maternal organ from rats treated with water (Control) or Croton urucurana aqueous extract during pregnancy.

\begin{tabular}{|c|c|c|c|c|}
\hline & \multicolumn{4}{|l|}{ Groups } \\
\hline & Control $(n=13)$ & Treated $200(n=13)$ & Treated $400(n=13)$ & Treated $800(n=12)$ \\
\hline Heart (g/100 g) & $0.32 \pm 0.03$ & $0.32 \pm 0.02$ & $0.31 \pm 0.03$ & $0.38 \pm 0.06^{*}, \# \$$ \\
\hline Liver (g/100 g) & $4.18 \pm 0.30$ & $3.81 \pm 0.30$ & $4.05 \pm 0.59$ & $4.09 \pm 0.53$ \\
\hline Spleen (g/100 g) & $0.27 \pm 0.07$ & $0.23 \pm 0.04$ & $0.22 \pm 0.04$ & $0.25 \pm 0.03$ \\
\hline Right kidney (g/100 g) & $0.30 \pm 0.03$ & $0.31 \pm 0.03$ & $0.30 \pm 0.02$ & $0.29 \pm 0.04$ \\
\hline Left kidney (g/100 g) & $0.29 \pm 0.02$ & $0.30 \pm 0.03$ & $0.29 \pm 0.02$ & $0.29 \pm 0.04$ \\
\hline
\end{tabular}

Data shown as mean \pm standard deviation (SD).

${ }^{*} p<0.05$ - compared to Control group (ANOVA followed Tukey's Multiple Comparison test).

${ }^{*} p<0.05$ - compared to Treated 200 group (ANOVA followed Tukey's Multiple Comparison test).

$\$ p<0.05$ - compared to Treated 400 group (ANOVA followed Tukey's Multiple Comparison test)

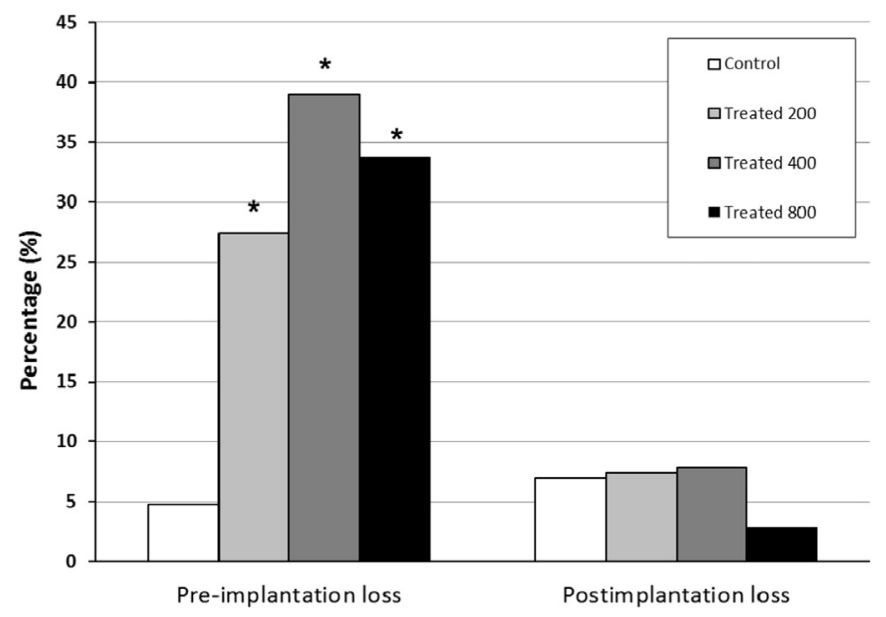

Fig. 1. Pre and postimplantation loss rates of rats treated with water (Control) or Croton urucurana aqueous extract during pregnancy. ${ }^{*} \mathrm{p}<0.05$ - compared to Control group (Fisher's Exact test).

Table 4

Reproductive outcome and fetal/placental weights from rats treated with water (Control) or Croton urucurana aqueous extract during pregnancy.

\begin{tabular}{|c|c|c|c|c|}
\hline & \multicolumn{4}{|l|}{ Groups } \\
\hline & Control $(n=13)$ & $\begin{array}{l}\text { Treated } 200 \\
(n=13)\end{array}$ & $\begin{array}{l}\text { Treated } 400 \\
(n=13)\end{array}$ & $\begin{array}{l}\text { Treated } 800 \\
(n=12)\end{array}$ \\
\hline \multicolumn{5}{|l|}{$\begin{array}{l}\text { Fetal body } \\
\quad \text { weight }(\mathrm{g})^{\mathrm{a}}\end{array}$} \\
\hline Mean \pm SD & $5.16 \pm 0.50$ & $5.08 \pm 0.44$ & $4.83 \pm 0.54^{* \#}$ & $4.86 \pm 0.51^{* \#}$ \\
\hline $\begin{array}{l}\text { SPA Fetuses } \\
(\%)^{\mathrm{b}}\end{array}$ & 4.08 & 2.86 & $15.04^{* \#}$ & $13.59^{* \#}$ \\
\hline $\begin{array}{l}\text { APA Fetuses } \\
(\%)^{\mathrm{b}}\end{array}$ & 93.88 & 94.29 & $84.07^{* \#}$ & $83.50^{* \#}$ \\
\hline $\begin{array}{l}\text { LPA Fetuses } \\
(\%)^{\mathrm{b}}\end{array}$ & 2.04 & 2.86 & 0.88 & 2.91 \\
\hline \multicolumn{5}{|l|}{$\begin{array}{l}\text { Placental } \\
\quad \text { weight (g) }\end{array}$} \\
\hline Mean \pm SD & $0.42 \pm 0.08$ & $0.47 \pm 0.14$ & $0.42 \pm 0.07^{\#}$ & $0.43 \pm 0.10$ \\
\hline \multicolumn{5}{|l|}{$\begin{array}{l}\text { Placental } \\
\quad \text { efficiency }^{\mathrm{a}}\end{array}$} \\
\hline Mean \pm SD & $12.62 \pm 2.03$ & $11.50 \pm 2.46^{*}$ & $11.64 \pm 1.75^{*}$ & $11.60 \pm 1.97$ \\
\hline
\end{tabular}

Legend: SPA - small for pregnancy age; APA - appropriate for pregnancy age; LPA large for pregnancy age.

Data shown as mean \pm standard deviation (SD) and proportions (\%).

${ }^{*} p<0.05$ - compared to Control group ('aNOVA followed Tukey's Multiple Comparison test; ${ }^{\mathrm{b}}$ Fisher's Exact test).

${ }^{*} p<0.05$ - compared to Treated 200 group ('ANOVA followed Tukey's Multiple Comparison test; ${ }^{\mathrm{b}}$ Fisher's Exact test). plantation loss rate of the treated groups with C. urucurana (200, 400 and $800 \mathrm{mg} / \mathrm{kg}$ ) was higher, indicating a failure of embryo implantation. Previous reports indicate the presence of saponinis, steroids, anthocyamdins, catechins and diterpenes in latex of C. urucurana (Gurgel et al., 2001; Rao et al., 2007; Oliveira et al., 2008). According to Hyacinth and Nwocha (2011) alkaloids, tannins, flavonoids and terpenoids are involved with contraceptive effects. Diterpenoids are very common in Croton, corresponding to clerodanes, cembranoid, halimanes, kauranes, labdanes, phorbol esters, trachylobanes and sarcopetalanes. Many pharmacological studies with Croton constituents dealt with the clerodane trans-dehydrocrotonin (DCTN), which presents a wide diversity of effects, including hypolipidemic, hypoglycaemic, anti-oestrogen and anti-cancer (Salatino et al., 2007). DCTN presented antioestrogenic activity in immature rat as a model system for bioassay of oestrogen and for an anti-implantation effect in regularly cycling rats (Maciel et al., 2000). These facts might explain our results related to antiimplantational effect caused by possible antioestrogenic activity of clerodane. Moreover, Almeida and Lemonica (2000) propose that the increased preimplantation loss rate could be associated with a relaxant effect of the diterpenoids on the oviduct motility. Another explanation for increased preimplantation rate might be due to a Croton-induced indirect injury leading to an abnormal uterine transport, which impaired synchronism between embryo attachment and endometrial receptivity to an adequate implantation process (Aplin and Kimber, 2004).

The embryos had succeeded in implantation developed regardless of Croton treatment as confirmed by no change postimplantational loss rate. On the other hand, C. urucurana latex at doses of 400 and $800 \mathrm{mg} / \mathrm{kg}$ decreased fetal body weight, with increase in SPA fetuses and consequently a decreased of APA fetuses. The reduction in fetal body weight is indicator of intrauterine growth retardation (Alkalay et al., 1998; Kim et al., 2004). Therefore, maternal toxicity and the lowest maternal food intake presented in the treated groups may be responsible for intrauterine growth retardation. Chernoff et al. (2008) showed that maternal toxicity might cause change fetal development. Animals treated with this plant presented an impaired placental development, as verified by reduced placental efficiency. Changes in placental efficiency can occur by alterations in the weight of the fetus, placenta or both. The placental efficiency is a parameter used for evaluation of placental function in related to maternal-fetal exchange (Fowden et al., 2009). In all treated groups with $C$. urucurana, the placental efficiency was decreased, also contributing for intrauterine growth restriction presented.

The treated 800 group presented an increased frequency of skeletal anomalies. The most common skeletal anomalies in fetuses were incomplete ossification of cranius and unossified and abnormally shaped sternebra. Abnormally shaped sternebra can be associated to maternal stress, and the permanent effects of this variation are unclear (Tyl et al., 2007). The treatment with higher doses (400 and $800 \mathrm{mg} /$ $\mathrm{kg}$ ) showed increase in visceral anomalies frequency (mainly dilated 
Table 5

Frequency of fetal anomalies from rats treated with water (Control) or Croton urucurana aqueous extract during pregnancy.

\begin{tabular}{|c|c|c|c|c|}
\hline \multirow[t]{2}{*}{ Variables } & \multicolumn{4}{|l|}{ Groups } \\
\hline & Control & Treated 200 & Treated 400 & Treated 800 \\
\hline \multicolumn{5}{|l|}{ External anomalies } \\
\hline Number fetuses examined (litter) & $147(13)$ & $110(11)$ & $107(10)$ & $103(10)$ \\
\hline Total number of fetuses (\%) with alteration ${ }^{\mathrm{b}}$ & $0(0.0 \%)$ & $1(0.9 \%)$ & $0(0.0 \%)$ & $1(1.0 \%)$ \\
\hline Mean $\%$ fetuses with alteration per litter $(\text { mean } \pm S D)^{a}$ & $0.0 \pm 0.0$ & $0.7 \pm 2.3$ & $0.0 \pm 0$ & $1.0 \pm 3.2$ \\
\hline Body edema ${ }^{b}$ & $0(0.0 \%)$ & $0(0.0 \%)$ & $0(0.0 \%)$ & $1(1.0 \%)$ \\
\hline Gastrosquisis $^{\mathrm{b}}$ & $0(0.0 \%)$ & $1(0.9 \%)$ & $0(0.0 \%)$ & $0(0.0 \%)$ \\
\hline \multicolumn{5}{|l|}{ Skeletal anomalies } \\
\hline Number fetuses examined (litter) & 79 (13) & $58(11)$ & $55(10)$ & $53(10)$ \\
\hline Total number of fetuses (\%) with alteration ${ }^{\mathrm{b}}$ & $35(44.3 \%)$ & $31(53.4 \%)$ & $32(58.2 \%)$ & $46(86.8 \%)^{*}$ \\
\hline Mean $\%$ fetuses with alteration per litter $(\text { mean } \pm \mathrm{SD})^{\mathrm{a}}$ & $44.1 \pm 23.1$ & $53.5 \pm 23.5$ & $50.1 \pm 32.7$ & $88.1 \pm 13.0$ \\
\hline Incomplete ossification of cranium $^{b}$ & $1(1.3 \%)$ & $1(2.8 \%)$ & $4(7.3 \%)$ & $7(13.2 \%)^{*}$ \\
\hline Abnormally shaped of vert. centrum ${ }^{b}$ & $0(0.0 \%)$ & $0(0.0 \%)$ & $0(0.0 \%)$ & $1(1.9 \%)^{*, *}$ \\
\hline Bipartite ossif. of vertebral centrum ${ }^{b}$ & $0(0.0 \%)$ & $0(0.0 \%)$ & $0(0.0 \%)$ & $1(1.9 \%)$ \\
\hline Supranumerary rib ${ }^{b}$ & $4(5.0 \%)$ & $3(5.2 \%)$ & $4(7.3 \%)$ & $6(13.0 \%)$ \\
\hline Bipartite $r i b^{b}$ & $0(0.0 \%)$ & $1(1.7 \%)$ & $0(0.0 \%)$ & $0(0.0 \%)$ \\
\hline Wavy rib ${ }^{b}$ & $2(2.5 \%)$ & $1(1.7 \%)$ & $2(3.6 \%)$ & $2(3.8 \%)$ \\
\hline Sternebra agenesis ${ }^{b}$ & $3(3.8 \%)$ & $2(3.4 \%)$ & $0(0.0 \%)$ & $1(1.9 \%)$ \\
\hline Incomplete ossification of sternebra ${ }^{b}$ & $19(24.1 \%)$ & $17(29.3 \%)$ & $12(21.8 \%)$ & $44(83.0 \%)^{*, \#, \$}$ \\
\hline Bipartite sternebra ${ }^{b}$ & $2(2.5 \%)$ & $0(0.0 \%)$ & $0(0.0 \%)$ & $0(0.0 \%)$ \\
\hline Abnormally shaped sternebra ${ }^{b}$ & $15(18.9 \%)$ & $22(37.9 \%)^{*}$ & $28(50.9 \%)^{*}$ & $30(56.6 \%)^{*}$ \\
\hline \multicolumn{5}{|l|}{ Visceral anomalies } \\
\hline Number fetuses examined (litter) & $68(13)$ & $50(11)$ & $52(10)$ & $50(10)$ \\
\hline Total number of fetuses (\%) with alteration ${ }^{\mathrm{b}}$ & $21(30.9 \%)$ & $20(40.0 \%)$ & $31(66.0 \%)^{*, *}$ & $27(54.0 \%)^{*}$ \\
\hline Mean $\%$ fetuses with alteration per litter $(\text { mean } \pm S D)^{a}$ & $29.9 \pm 27.6$ & $41.4 \pm 22.6$ & $64.3 \pm 34.0$ & $53.6 \pm 35.5$ \\
\hline Microphthalmia ${ }^{b}$ & $0(0.0 \%)$ & $0(0.0 \%)$ & $1(1.9 \%)$ & $0(0.0 \%)$ \\
\hline Dilated trachea ${ }^{b}$ & $0(0.0 \%)$ & $2(4.7 \%)$ & $14(26.9 \%)^{*, *}$ & $11(22.0 \%)^{*, \#}$ \\
\hline Dilated renal pelvis ${ }^{b}$ & $1(1.5 \%)$ & $0(0.0 \%)$ & $1(1.9 \%)$ & $0(0.0 \%)$ \\
\hline Hydroureter $^{b}$ & $19(27.9 \%)$ & $17(34.0 \%)$ & $21(40.4 \%)$ & $20(40.0 \%)$ \\
\hline Hydronephrosis ${ }^{b}$ & $0(0.0 \%)$ & $1(2.3 \%)$ & $1(1.9 \%)$ & $0(0.0 \%)$ \\
\hline Kidney agenesis ${ }^{b}$ & $1(1.5 \%)$ & $0(0.0 \%)$ & $0(0.0 \%)$ & $0(0.0 \%)$ \\
\hline Ectopic testis ${ }^{b}$ & $1(1.5 \%)$ & $0(0.0 \%)$ & $1(1.9 \%)$ & $0(0.0 \%)$ \\
\hline
\end{tabular}

Data shown as mean \pm standard deviation (SD) and proportions (\%).

${ }^{*} p<0.05$ - compared to Control group (aNOVA followed Tukey's Multiple Comparison test; ${ }^{\mathrm{b}}$ Fisher's Exact test).

\# $p<0.05$ - compared to Treated 200 group ( ${ }^{\mathrm{a} A N O V A}$ followed Tukey's Multiple Comparison test; ${ }^{\mathrm{b}}$ Fisher's Exact test).

$\$ p<0.05$ - compared to Treated 400 group ( ${ }^{\mathrm{A} A N O V A}$ followed Tukey's Multiple Comparison test; ' ${ }^{\mathrm{b}}$ Fisher's Exact test).

trachea). Exposure to xenobiotics during pregnancy may adversely affect normal development of the fetus (Chahoud et al., 1999). Studies showed that treatment with plants during pregnancy may cause damage to offspring development (Oliveira et al., 2010; Dallaqua et al., 2013; Soares et al., 2015).

\section{Conclusion}

Croton urucurana extract orally administered orally to rats from day $0-21$ of pregnancy caused maternal toxicity, which contributed for impairment embryo fetal development. These results showed that the indiscriminate use of plants during pregnancy should be avoided to prevent potential risk on maternal health as well as their offspring.

\section{Acknowledgement}

The authors are thankful to the staff of the Laboratory System Physiology and Reproductive Toxicology (FisioTox), especially to Thais Leal Silva, for auxiliary practical procedures.

\section{References}

Al-Habori, M., Al-Aghbari, A., Al-Mamary, M., Baker, M., 2002. Toxicological evaluation of Catha edulis leaves: a long term feeding experiment in animals. J. Ethnopharmacol. 83, 209-217.

Alkalay, A.L., Graham, J.M., Jr, Pomerance, J.J., 1998. Evaluation of neonates born with intrauterine growth retardation: review and practice guidelines. J. Perinatol. 18, $142-151$.

Almeida, F.C.G., Lemonica, I.M.P., 2000. The toxic effects of Coleus barbatus B. on the different periods of pregnancy in rats. J. Ethnopharmacol. 73, 53-60.

Aplin, J.D., Kimber, S.J., 2004. Trophoblast-uterine interactions at implantation.
Reprod. Biol. Endocrinol. 48, 1-12.

Babieri, D.S.V., Tonial, F., Lopez, P.V.A., Maia, B.H.L.N., Santos, G.D., Ribas, M.O., Glienke, C., Vicente, V.A., 2014. Antiadherent activity of Schinus terebinthifolius and Croton urucurana extracts on in vitro biofilm formation of Candida albicans and Streptococcus mutans. Arch. Oral. Biol. 59, 887-896.

Chahoud, I., Ligensa, A., Dietzel, L., Faqi, A.S., 1999. Correlation between maternal toxicity and embryo/fetal effects. Reprod. Toxicol. 13, 375-381.

Chernoff, N., Rogers, E.H., Gage, M.I., Francis, B.M., 2008. The relationship of maternal and fetal toxicity in developmental toxicology bioassays with notes on the biological significance of the "no observed adverse effect level". Reprod. Toxicol. 25, 192-202.

Cicha, I., Suzuki, Y., Tateishi, N., Maeda, N., 1999. Rheological changes in human red blood cells under oxidative stress. Pathophysiol 6, 121-128.

Cordeiro, K.W., Pinto, L.A., Formagio, A.S.N., Andrade, S.F., Kassuya, C.A.L., Freitas, K.C., 2012. Antiulcerogenic effect of Croton urucurana Baillon bark. J. Ethnopharmacol. 143, 331-337.

Cordeiro, K.W., Felipe, J.L., Malange, K.F., Do Prado, P.R., Figueiredo, P.O., Garcez, F.R., Freitas, K.C., Garcez, W.S., Toffoli-Kadri, M.C., 2016. Anti-inflammatory and antinociceptive activities of Croton urucurana Baillon bark. J. Ethnopharmacol. 183, 128-135.

Dallaqua, B., Saito, F.H., Rodrigues, T., Calderon, I.M., Rudge, M.V., Volpato, G.T., Damasceno, D.C., 2013. Azadirachta indica treatment on the congenital malformations of fetuses from rats. J. Ethnopharmacol. 150, 1109-1113.

Damasceno, D.C., Silva, H.P., Vaz, G.F., Vasques-Silva, F.A., Calderon, I.M., Rudge, M.V., Campos, K.E., Volpato, G.T., 2012. Diabetic rats exercised prior to and during pregnancy: maternal reproductive outcome, biochemical profile, and frequency of fetal anomalies. Reprod. Sci. 20, 730-738.

De Simone, G., Devereux, R.B., Chinali, M., Best, L.G., Lee, E.T., Welty, T.K., 2005. Association of blood pressure with blood viscosity in american indians: the Strong Heart Study. Hypertension 45, 625-630.

Environmental Protection Agency (EPA), 1996. Guidelines for reproductive toxicity risk assessment. Washington: EPA/630/R-96/009.

Esmeraldino, L.E., Souza, A.M., Sampaio, S.V., 2005. Evaluation of the effect of aqueous extract of Croton urucurana Baillon (Euphorbiaceae) on the hemorrhagic activity induced by the venom of Bothrops jararaca, using new techniques to quantify hemorrhagic activity in rat skin. Phytomedicine 12, 570-576.

Fowden, A.L., Sferruzzi-Perri, A.N., Coan, P.M., Constancia, M., Burton, G.J., 2009. Placental efficiency and adaptation: endocrine regulation. J. Physiol. 587, 3459-3472. 
Giannini, E.G., Testa, R., Savarino, V., 2005. Liver enzyme alteration: a guide for clinicians. C. M. A. J. 172, 367-379.

Gurgel, L.A., Silva, R.M.S., Santos, F.A., Martins, D.T.O., Mattos, P.O., Rao, V.S.N., 2001. Studies on the antidiarrhoeal effect of Dragon's Blood from Croton urucurana. Phytother. Res. 15, 319-322.

Gurgel, L.A., Martins, D.T.O., Mattos, P.O., Rao, V.S., 2002. Estudo da atividade antidiarréica e antissecretória intestinal do látex do Croton urucurana Baill. Rev. Bras. Farmacogn. 12, 39-42.

Gurgel, L.A., Sidrim, D.T., Martins, D.T., Cechinel-Filho, V., Rao, V.S., 2005. In vitro antifungal activity of dragon's blood from Croton urucurana against dermatophytes. J. Ethnopharmacol. 97, 409-412.

Hyacinth, A.A., Nwocha, U.C., 2011. Antifertility activity of aqueous ethanolic extract of Hymenocardia acida stem bark in female rats. Iran. J. Reprod. Med. 9, 217-222.

Kim, J.C., Kim, S.H., Shin, D.H., Ahn, T.H., Kim, H.C., Kim, Y.B., Jiang C.Z., Han, J., Chung, M.K., 2004. Effects of prenatal exposure to the environmental pollutant 2bromopropane on embryo-fetal development in rats. Toxicology 196, 77-86.

Knopfholz, J., Disserol, C.C.D., Pierin, A.J., Schirr, F.L., Streisky, L., Takito, L.L. Ledesma, P.M., Faria-Neto, J.R., Olandoski, M., Cunha, C.L.P., Bandeira, A.M., 2014. Validation of the Friedewald formula in patients with metabolic syndrome. Cholesterol 2014, 1-5.

Li, G., He, H., Yan, H., Zhao, Q., Yin, D., 2010. Does carbonyl stress cause increased blood viscosity during storage? Clin. Hemorheol. Microcirc. 44, 145-154.

Maciel, M.A., Pinto, A.C., Arruda, A.C., Pamplona, S.G., Vanderlinde, F.A., Lapa, A.J., Echevarria, A., Grynberg, N.F., Côlus, I.M., Farias, R.A., Luna Costa, A.M., Rao, V.S., 2000. Ethnopharmacology, phytochemistry and pharmacology: a successful combination in the study of Croton cajucara. J. Ethnopharmacol. 70, 41-55.

Moreira, D.L., Teixeira, S.S., Moteiro, M.H.D., De-Oliveira, A.X., Paumgartten, F.J.R., 2014. Traditional use and safety of herbal medicines. Rev. Bras. Farmacogn. 24, 248-257.

Oliveira, I.S., Lima, J.C.S., Silva, R.M., Martins, D.T.O., 2008. Triagem da atividade antibacteriana in vitro do látex e extratos de Croton urucurana Baillon. Rev. Bras. Farmacogn. 18, 587-593.

Oliveira, C.D., Moreira, C.Q., Sá, L.R., Spinosa, H.S., Yonamine, M., 2010. Maternal and developmental toxicity of ayahuasca in Wistar rats. Birth Defects Res. B. Dev.
Reprod. Toxicol. 89, 207-212.

Rao, V.S., Gurgel, L.A., Lima-Júnior, R.C.P., Martins, D.T.O., Cechinel-Filho, V., Santos, F.A., 2007. Dragon's blood from Croton urucurana (Baill.) attenuates visceral nociception in mice. J. Ethnopharmacol. 113, 357-360.

Salatino, A., Salatino, M.L.F., Negri, G., 2007. Traditional uses, chemistry and pharmacology of Croton species (Euphorbiaceae). J. Braz. Chem. Soc. 18, 11-33.

Salewski, E., 1964. Farbemethode zum markroskopishen nachweis von implantatconsstellen an uterus der ratter naunyn schmuderbergs. N-S. Arch. Pharmacol, 247-367.

Santos, T.M., Sinzato, Y.K., Gallego, F.Q., Lessi, I.L., Volpato, G.T., Dallaqua, B., Damasceno, D.C., 2015. Extracellular HSP70 levels in diabetic environment in rats. Cell Stress Chaperon-. 20, 595-603.

Simionatto, E., Bonani, V.F.L., Morel, B.A.F., Poppi, N.R., Raposo Júnior, J.L., Stuker, C.Z., Peruzzo, G.M., Peres, M.T.L.P., Hessa, S.C. 2007. Chemical composition and evaluation of antibacterial and antioxidant activities of the essential oil of Croton urucurana Baillon (Euphorbiaceae) stem Bark. J. Braz. Chem. Soc. 18, 879-885.

Soares, T.S., Damasceno, D.C., Kempinas, W.G., Resende, F.M., Correa dos Santos, M.A., Hiruma-Lima, C.A., Volpato, G.T., 2015. Effect of Himatanthus sucuuba in maternal reproductive outcome and fetal anomaly frequency in rats. Birth Defects Res. B Dev. Reprod. Toxicol. 104, 190-195.

Staples, R.E., Schnell, V.L., 1964. Refinements in rapid clearing technique in the KOHalizarin red S method for fetal bone. Stain. Technol. 39, 61-63.

Tyl, R.W., Chernoff, N., Rogers, J.M., 2007. Altered axial skeletal development. Birth Defects Res. B. Dev. Reprod. Toxicol. 80, 451-472.

Volpato, G.T., Francia-Farje, L.A.D., Damasceno, D.C., Oliveira, R.V., Hiruma-Lima, C.A., Kempinas, W.G., 2015. Effect of essential oil from Citrus aurantium in maternal reproductive outcome and fetal anomaly incidence in rats. An. Acad. Bras. Ciênc. 87, 307-312.

Webster, G.L., 1993. A provisional synopsis of the sections of the genus Croton (Euphorbiaceae). Taxon 42, 793-823.

Wilson, J.G., 1965. Methods for administering agents and detecting malformations in experimental animal. In: Wilson, J.G., Warkany, J. (Eds.), Teratology: Principles and Techniques. University of Chicago Press, Chicago, (pp 262 - 27). 